\title{
Enhancement of cartilage repair through the addition of growth plate chondrocytes in an immature skeleton animal model
}

\author{
Ryszard Tomaszewski ${ }^{1,2}$, Łukasz Wiktor $^{1 *}$ (D) and Artur Gap
}

\begin{abstract}
Background: The treatment of articular cartilage damage is a major clinical problem. More often, this clinical issue affects children, which forces doctors to find the best treatment method.

Methods: The aim of this experimental study on 2-month-old Landrace pigs was to compare the results of two cartilage defect treatments: (1) filling the cartilage defect with a scaffold incubated with bone marrow aspirate supplemented with growth plate chondrocytes (the CELLS group) and (2) filling the cartilage defect with an empty scaffold implanted after drilling the subchondral bone (the CTRL group). The treatment outcomes were assessed macroscopically and microscopically.

Results: Based on the macroscopic evaluation, all animals showed a nearly normal morphology, with an average of 9.66/12 points (CTRL) and 10.44/12 points (CELLS). Based on the microscopic evaluation, 1 very good result and 8 good results were obtained in the CTRL group, with an average of $70.44 \%$, while 5 very good results and 4 good results were obtained in the CELLS group, with an average of $79.61 \%$.

Conclusions: (1) Growth plate chondrocytes have high chondrogenic potential and thus offer new possibilities for cartilage cell therapy. (2) The implantation of a scaffold loaded with bone marrow-derived MSCs (mesenchymal stem cells) and growth plate chondrocytes into a cartilage defect is a good therapeutic method in immature patients. (3) Cartilage repair based on a scaffold with bone marrow aspirate-derived cells supplemented with autologous growth plate chondrocytes achieves better results than repair with marrow stimulation and a hyaluronic acid-based scaffold (overall microscopic rating). (4) Chondrocyte clustering is a manifestation of the cartilage repair process but requires further observation.
\end{abstract}

Keywords: Articular cartilage, Chondrocyte, Trauma, Histological scoring system

\section{Background}

Due to its specific structure and highly specialised function, the treatment of damage to articular cartilage is a major clinical problem. Moreover, its structure, which consists of chondrocytes surrounded by an extracellular matrix, and its avascular character result in a low regenerative capacity. The chondron framework and orientation are closely associated with the microarchitecture, function, and location of articular cartilage, which further complicates the regeneration process. A number

\footnotetext{
* Correspondence: wiktor.ort@gmail.com

${ }^{1}$ Department of Pediatric Traumatology and Orthopedy, Silesian Medical University, Katowice, Poland

Full list of author information is available at the end of the article
}

of different treatment methods have been developed for both early and advanced stages of cartilage damage, but a definitive method has not yet been determined. Among all of the surgical procedures used for the treatment of cartilage damage, the following should be distinguished: arthroscopic debridement, bone marrow stimulation, osteochondral autografting, autologous chondrocyte implantation (ACI), and matrix-induced autologous chondrocyte implantation (MACI) $[1,2]$. The continuous development of regenerative medicine creates new possibilities for cartilage defect treatments involving cell therapy. Isolated and specially cultured cells can be injected into the joint, or via tissue engineering techniques, and can be implanted on special substrates 
directly in the site of cartilage damage. A variety of cells have been used, as reported in the literature, including autogenic chondrocytes, allogenic chondrocytes, mesenchymal stem cells (MSCs; most widely used; can be derived from bone marrow, blood, synovium, and synovial fluid), and human pluripotent stem cells (embryonic stem cells, ESCs; induced pluripotent stem cells, iPSCs); however, the best cells have yet to be identified [3-12]. The aim of our study was to compare the effects of treating cartilage damage with the two currently most popular techniques: marrow stimulation and autologous cell therapy. We chose the marrow stimulation technique as a reference point because it is a one-step method that does not require expensive instrumentation and has been widely used for many years. Based on the current literature, cell therapies are rapidly developing, with promising results [3]. Chondrocytes and MSCs are the most commonly used cells in cartilage tissue engineering $[2,4]$. In our opinion, the key point is to find a simple and optimal one-step surgical cartilage repair technique that restores hyaline cartilage. Due to the aforementioned facts, our study was designed to evaluate the effects of biological therapy based on the use of bone marrow-derived MSCs along with young chondrocytes isolated from growth plates. The proposed method combines the MACI technique with the clinical application of MSCs.

Our research was carried out using a developmental animal model because in everyday practice, we more often diagnose articular cartilage injuries in children in the Orthopedics Department. We wanted to focus on immature animals to mimic cartilage repair in children. Cartilage regeneration potential in children has been described to be more potent compared with adult patients. Moreover, children and adolescents have a greater capacity to spontaneous cartilage healing which correspond with better outcome, both after conservative and surgical treatment. Due to abovementioned, problem of cartilage damage in children should always be considered individually.

\section{Materials and methods}

The study group consisted of 10 pigs at the age of 12 weeks. Each animal was assigned a number, and the knee joints were divided into right $(\mathrm{R})$ and left $(\mathrm{L})$. Both hind legs of all animals were operated on; one side was treated with a hyaluronic acid-based scaffold and bone marrow cells via the marrow stimulation technique (the CTRL group), and the other side was treated with bone marrow cells from marrow aspirates supplemented with immature chondrocytes isolated from growth plates (the CELLS group). In the first stage of the experiment, in the operating room with the animal under analgosedation (atropine sulphate $0.05 \mathrm{mg} / \mathrm{kg}$ s.c., Polfarmex,
Kutno; ketamine hydrochloride $3 \mathrm{mg} / \mathrm{kg}$ i.m., Biowet, Puławy; and xylazine hydrochloride $1 \mathrm{mg} / \mathrm{kg}$ i.m., Riemser), we performed bone marrow aspiration.

\section{Bone marrow harvesting}

We used the Mini Marrowstim ${ }^{\text {Tu }}$ Concentration System (BIOMET). Each time, a bone marrow biopsy was performed from the posterior iliac spine to aspirate $30 \mathrm{ml}$ of specimen ( $3 \mathrm{ml}$ of heparin with $27 \mathrm{ml}$ of bone marrow aspirate). The specimens were centrifuged for $15 \mathrm{~min}$ at 3200 $\mathrm{rpm}$, yielding a 3-layer distribution consisting of a plasmarich layer, a cell-rich layer, and a red blood cell layer.

\section{Cell-rich concentrate preparation}

The isolated cell-rich concentrate was rinsed with Ham's F12. The gained solution was then centrifuged twice at $200 \mathrm{x}$ g for $5 \mathrm{~min}$ and rinsed each time with Ham's F12.

\section{Growth plate chondrocyte isolation}

Using the trepanning needle, which we used to aspirate the bone marrow, we retrieved a biopsy of the iliac growth cartilage, from which we isolated juvenile chondrocytes according to the following scheme: the growth plate sample was cut into $1 \mathrm{~mm}^{3}$ fragments and then washed with Ham's F12 (PAN Biotech, P-04-14500). The preparations were digested with Collagenase NB 4 (SERVA, 17454.02) at a concentration of $0.3 \mathrm{U} / \mathrm{ml}$ in Ham's F12 at $37^{\circ} \mathrm{C}$ for $6 \mathrm{~h}$. The solution was then centrifuged twice at $180 \times g$ for $10 \mathrm{~min}$ and rinsed each time with Ham's F12. The obtained cells were suspended in $100 \mu \mathrm{l}$ of Ham's F12 with 20\% serum. For each preparation, we controlled the process of chondrocyte isolation from the growth plate by microscopy.

\section{Scaffold preparation}

We cut the Hyalofast ${ }^{\circ}$ scaffold into 20 equal fragments similar to the predicted size of the joint cartilage defect. We chose Hyalofast because in the degradation process, hyaluronic acid is released into the lesion, creating a microenvironment rich in HA. Moreover, MSCs combined with Hyalofast have been shown to differentiate into chondrocytes for hyaline-like cartilage regeneration $[13,14]$. We divided the scaffolds into two groups. In the first group, after rinsing with Ham's F12, the scaffolds were incubated with cell-rich concentrate for $5 \mathrm{~h}$ and then with chondrocytes isolated from the iliac growth plate for another $7 \mathrm{~h}$. In the second group, the scaffolds consisted only of scaffolds without added cells. Thus, the prepared scaffolds were ready for implantation. In stage II of the experiment in the operating theatre, after prior medication according to the scheme shown above, the pigs were anaesthetized using $1 \%$ propofol $1.5-2.5 \mathrm{mg} / \mathrm{kg}$ i.v. (Fresenius Kabi, Austria GmbH) 
and fentanyl $2.5 \mathrm{mg} / \mathrm{kg}$ m.c. i.v. and inhaled isoflurane $0.5 \%$ volume.

\section{Cartilage damage induction and scaffold implantation} While monitoring the vital parameters of the animals, we performed a mini-arthrotomy separately for the right and left knees. Each time, we made a cartilage defect on the surface of the medial femoral condyle with a diameter of $6 \mathrm{~mm}$. We paid much attention to gentle and thorough removal of the joint cartilage such that the cavity reached the subchondral bone without secondary damage. In one study group (CTRL), we implanted an empty scaffold into the defect and to provide additional cells for cartilage healing, and we perforated the subchondral bone three times for each defect using a 1$\mathrm{mm}$-diameter Kirschner wire to a depth of $6 \mathrm{~mm}$. In the second study group (CELLS), we implanted a scaffold incubated with cells without drilling the subchondral bone. The experimental scheme is presented in Tables 1 and 2. Every graft was checked prior to implantation to confirm the graft and animal number. Every graft was stabilised with 2 vicryl 5-0 sutures (Johnson \& Johnson). After stable graft placement confirmation, we closed the surgical wound and secured the operated limb with a sterile dressing. The animals were allowed to walk freely in their cages.

\section{Morphological and histological evaluations}

After 12 weeks from the day of surgery, the animals were sacrificed (Morbitol $1.6 \mathrm{mg} / \mathrm{kg}$ i.v.), and the 20 treated knees were collected. For each specimen, the patella was removed to provide direct visualisation of the joint, which facilitated morphological evaluation of the treated cartilage according to the ICRS classification system (Additional file 1: Table S1). The preparations were then fixed in $10 \%$ formaldehyde. After sample decalcification (using TBD-2) and sectioning the material containing regenerated joint cartilage ( $5 \mu \mathrm{m}$ thick), the histological preparations were stained with haematoxylin and eosin,
Safranin O, and Masson's trichrome. The histological results were independently evaluated by two pathologists (RT, ŁW) using an Olympus BX51 microscope (Olympus America, Inc., Melville, NY). The ICRS II scale was used for the microscopic evaluation of regeneration (Additional file 2: Table S2).

\section{Statistical analysis}

To verify the difference between the mean measurements in the two groups, i.e. treatment with scaffolds containing cell-rich concentrate and chondrocytes (the CELLS group) and scaffolds with no cells (the CTRL group) for each parameter, we used Student's $t$ test and the non-parametric Wilcoxon test based on Bayesian statistics.

\section{Results}

In one pig (animal designated no. 4), postoperative wound infection was observed. Due to confirmation of the infectious process of the knee (morphologically and histologically), preparations from $4 \mathrm{R}$ and $4 \mathrm{~L}$ were excluded from further evaluations. Based on the obtained results, both methods achieved good and very therapeutic effects. Macroscopic evaluation was performed according to the ICRS classification system, and in the group of joints treated with scaffolds without cells, all specimens showed a nearly normal morphology, with an average score of $9.66 / 12$ points. In the group of joints treated with scaffolds incubated with cells, all joints similarly showed a nearly normal morphology, with an average score of $10.44 / 12$ points. Based on the microscopic evaluation, 1 very good result and 8 good results were obtained in the group of joints treated with scaffolds without cells, with an average of $70.44 \%$; in the group of joints treated with scaffolds incubated with cells, 5 very good results and 4 good results were obtained, with an average of $79.61 \%$. The results were averaged and are presented in Tables 3 and 4. The histological evaluation revealed significantly better

Table 1 CTRL group-experiment scheme

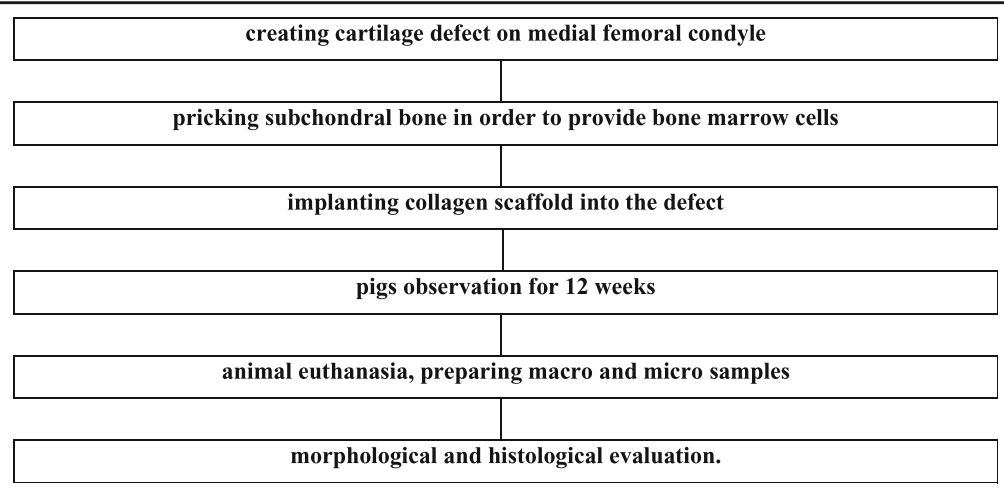


Table 2 CELLS group-experiment scheme

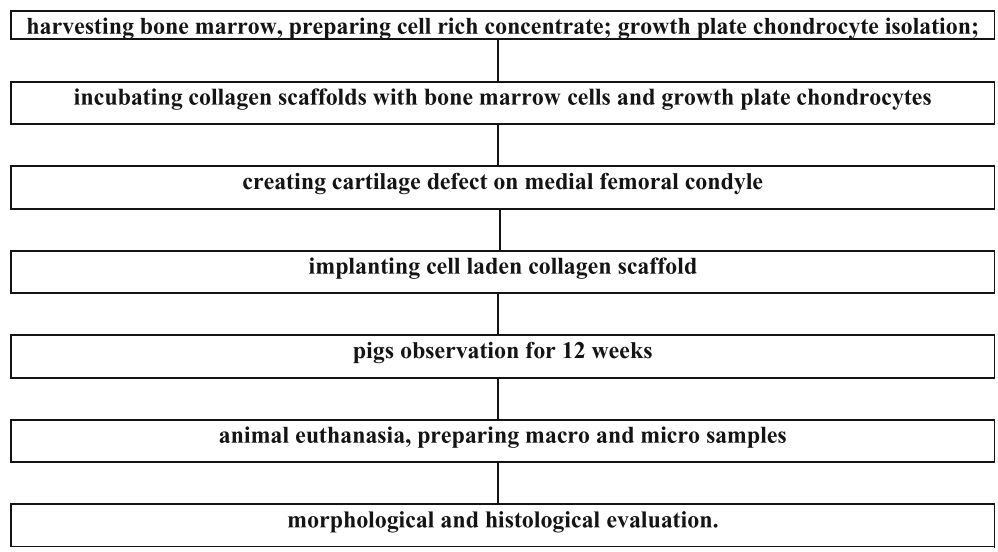

results in the CELLS group in terms of the tissue morphology $(p<0.01)$, matrix staining $(p<0.01)$, tidemark formation $(p<0.001)$, and overall assessment $(p<$ $0.05)$. The averaged results of all evaluated parameters were better for the CELLS group, indicating a better overall rating $(p<0.01)$. The results are shown in Table 5 and Fig. 1. More frequently, we found subchondral bone abnormalities in the CTRL group. Notably, we did not observe problems with graft integration in the CELLS group, and basal integration in this group was significantly better than that in the CTRL group $(p<0.01)$. With the exception of one pig, we did not observe lymphocytic infiltration as a response to scaffold implantation. We found a correlation between increased vascularization and a poorer overall rating, but it was not statistically significant. The presence of chondrocyte clusters in the two groups was analysed. By assessing the preparations, we found more chondrocytes forming clusters in the CELLS group (Table 6). Student's $t$ test showed a statistically significant difference in the presence of clusters in the middle $(p<0.05)$ and marginal zones $(p<0.01)$. The Wilcoxon test showed a statistically significant difference in the same parameters identified by Student's $t$ test and for clusters in the superficial zone. According to Cohen's $d$, the strength of the variable for the middle and marginal zones was large, and the strength for the superficial zone was average. The results are shown in Table 7 and Fig. 2. Representative results are shown in Figs. 3 and 4.

\section{Discussion}

Articular cartilage is a highly specialised tissue. Due to poor vascularity, its regenerative abilities are very limited [15]. Many authors have emphasised that despite various treatment methods, it is not possible to restore articular cartilage, only cartilage-like tissue [16-18].

In our experiment, we used 2-month-old Landrace pigs. Due to relatively large animal size, we could perform less invasive and more precise surgical procedures. Additionally, we could obtain growth plate chondrocytes. The similar tissue compliance genotype of this model to those of humans will make it easier to relate the results to the human population and implement the tested method in clinical practice [17]. Children and adolescents have a greater potential to spontaneous cartilage healing which correspond with better outcome. Moreover, stem cells in children are present in greater numbers and are much more able to divide than in adults and that is why biological treatment is a good alternative for immature patients. Indications for surgery are comparable for children and adult patients, but due to regeneration potential, there are no clear guidelines

Table 3 Macroscopic evaluation of cartilage according to ICRS

\begin{tabular}{|c|c|c|c|c|c|c|c|c|c|c|c|c|c|c|c|c|c|c|}
\hline & $1 \mathrm{~L}$ & $2 \mathrm{P}$ & $3 \mathrm{~L}$ & $5 P$ & $6 P$ & $7 \mathrm{P}$ & $8 \mathrm{P}$ & $9 \mathrm{P}$ & $10 \mathrm{P}$ & $1 \mathrm{P}$ & $2 \mathrm{~L}$ & $3 P$ & $5 \mathrm{~L}$ & $6 \mathrm{~L}$ & $7 \mathrm{~L}$ & $8 \mathrm{~L}$ & $9 \mathrm{~L}$ & $10 \mathrm{~L}$ \\
\hline Degree of defect repair & 3 & 3 & 3 & 3 & 3 & 3 & 3 & 3 & 3 & 3 & 4 & 3 & 3 & 3 & 4 & 3 & 3 & 3 \\
\hline Integration of border zone & 4 & 4 & 4 & 3 & 4 & 3 & 4 & 4 & 3 & 4 & 4 & 4 & 4 & 4 & 4 & 4 & 4 & 4 \\
\hline Macroscopic appearance & 3 & 3 & 3 & 2 & 2 & 3 & 3 & 4 & 4 & 4 & 4 & 3 & 3 & 2 & 3 & 4 & 4 & 3 \\
\hline Overall assessment & 10 & 10 & 10 & 8 & 9 & 9 & 10 & 11 & 10 & 11 & 11 & 11 & 9 & 9 & 11 & 11 & 11 & 10 \\
\hline Scaffold with cells_-CELLS & & & & & & & & & & + & + & + & + & + & + & + & + & + \\
\hline Scaffold without cells-CTRL & + & + & + & + & + & + & + & + & + & & & & & & & & & \\
\hline
\end{tabular}


Table 4 Microscopic evaluation of cartilage according to ICRS

\begin{tabular}{llllllllllllllllllll}
\hline & $1 \mathrm{~L}$ & $2 \mathrm{P}$ & $3 \mathrm{~L}$ & $5 \mathrm{P}$ & $6 \mathrm{P}$ & $7 \mathrm{P}$ & $8 \mathrm{P}$ & $9 \mathrm{P}$ & $10 \mathrm{P}$ & $1 \mathrm{P}$ & $2 \mathrm{~L}$ & $3 \mathrm{P}$ & $5 \mathrm{~L}$ & $6 \mathrm{~L}$ & $7 \mathrm{~L}$ & $8 \mathrm{~L}$ & $9 \mathrm{~L}$ & $10 \mathrm{~L}$ \\
\hline Tissue morphology & 68 & 65 & 62 & 71 & 50.5 & 40 & 52 & 52 & 60 & 88 & 88 & 84 & 82.5 & 45 & 39 & 55 & 80 & 65 \\
Matrix staining & 79 & 53 & 55 & 75.5 & 32 & 59 & 34 & 47 & 25 & 90 & 89 & 90 & 94 & 30 & 59 & 61 & 68 & 45 \\
Cell morphology & 80 & 55 & 80 & 70 & 26.5 & 75 & 36 & 54 & 52 & 84 & 79 & 86.5 & 91.5 & 44 & 56 & 61.5 & 62 & 57 \\
Chondrocyte clustering & 40 & 48 & 55 & 65 & 56 & 62 & 60 & 55 & 65 & 45 & 50 & 65 & 55 & 52 & 55 & 52 & 55 & 56 \\
Surface architecture & 90 & 79 & 78 & 51.5 & 79.5 & 96 & 79 & 89 & 79 & 96 & 89 & 88 & 81 & 81 & 82 & 90 & 96 & 90 \\
Basal integration. & 90 & 88 & 89 & 75 & 77.5 & 85 & 82 & 73 & 82 & 95 & 95 & 94 & 85 & 81 & 84 & 92 & 91 & 85 \\
Formation of tidemark & 25 & 24 & 30 & 36 & 18 & 22 & 21 & 25 & 21 & 35 & 44 & 42 & 44 & 20 & 34 & 30 & 44 & 38 \\
Subchondral bone abnormalities & 84 & 55 & 89 & 48 & 47 & 70 & 90 & 65 & 88 & 93.5 & 95 & 95.5 & 89 & 76.5 & 65 & 91.5 & 95 & 96 \\
Inflammation & 100 & 100 & 100 & 62.5 & 82 & 100 & 82 & 75 & 97 & 100 & 100 & 100 & 77 & 80.5 & 92 & 89 & 95 & 100 \\
Abnormal calcification/ossification & 100 & 100 & 100 & 87 & 100 & 100 & 100 & 100 & 100 & 100 & 100 & 100 & 100 & 100 & 100 & 100 & 100 & 100 \\
Vascularization & 86 & 20 & 95 & 70 & 52 & 50 & 42 & 45 & 70 & 100 & 92.5 & 96 & 94 & 50 & 48 & 55 & 95 & 75 \\
Superficial assessment & 81 & 60 & 72.5 & 70 & 45 & 72 & 62 & 62 & 80 & 92 & 91.5 & 91.5 & 91.5 & 38 & 67 & 60 & 72 & 75 \\
Mid/deep zone assessment & 80 & 62 & 75 & 75.5 & 61 & 75 & 71 & 66 & 76 & 89 & 92 & 89 & 82 & 75 & 50 & 83 & 84 & 85 \\
Overall assessment & 84 & 65 & 75 & 64 & 61 & 71 & 69 & 74 & 71 & 90 & 93 & 91.5 & 80 & 68 & 60 & 78 & 80 & 76 \\
Scaffold with cells_CELLS & & & & & & & & & & + & + & + & + & + & + & + & + & + \\
Scaffold without cells_CTRL & + & + & + & + & + & + & + & + & + & & & & & & & & & &
\end{tabular}

designed for children. Type of surgery should always depend on the size, the location, and the stage of the cartilage defect. Determining study conditions, it is very difficult to choose a relatively large cartilage defect size to sufficiently reduce the possibility of spontaneous regeneration because in skeletally immature animals, spontaneous repair almost always occurs. Based on experiments carried out in mature animals, we chose the cartilage defect size to reduce spontaneous cartilage regeneration, and we gently removed the deep layer of articular cartilage to reveal the subchondral bone $[17,18]$. As a reference point, we chose to fill the defect with a hyaluronic acid-based scaffold combined with drilling the subchondral bone to provide marrow cells without

Table 5 Statistical analysis

\begin{tabular}{|c|c|c|c|c|c|c|c|c|c|c|c|c|}
\hline & \multirow[t]{2}{*}{$t$} & \multirow[t]{2}{*}{$\mathrm{BF}_{10}$} & \multirow[t]{2}{*}{ Z } & \multirow[t]{2}{*}{ Cohen's $d$} & \multicolumn{2}{|c|}{$95 \%$ Cl for Cohen's $d$} & \multicolumn{3}{|l|}{ CELLS } & \multicolumn{3}{|l|}{ CTRL } \\
\hline & & & & & Lower & Upper & $\bar{M}$ & SD & SE & $\bar{M}$ & SD & SE \\
\hline Tissue morphology & $2.97^{* *}$ & 4.04 & $-2.134^{*}$ & 0.99 & 0.16 & 1.78 & 69.56 & 19.11 & 6.37 & 57.78 & 9.98 & 3.33 \\
\hline Cell morphology & 2.23 & 2.23 & -1.96 & 0.74 & -0.02 & 1.47 & 69.56 & 22.82 & 7.61 & 51.11 & 18.82 & 6.27 \\
\hline Chondrocytes clustering & -1.00 & -1.00 & -0.91 & -033 & -1.00 & 0.35 & 69.11 & 16.50 & 5.50 & 58.67 & 19.25 & 6.42 \\
\hline Surface architecture & 2.11 & 2.11 & -1.72 & 0.70 & -0.05 & 1.42 & 53.89 & 5.40 & 1.80 & 56.22 & 8.18 & 2.73 \\
\hline Basal integration & $3.63^{* *}$ & 3.64 & $-2.55^{*}$ & 1.21 & 0.32 & 2.07 & 88.11 & 5.82 & 1.94 & 75.56 & 18.78 & 6.26 \\
\hline Formation of tidemark & $6.29^{* * *}$ & 6.29 & $-2.67^{* * *}$ & 2.10 & 0.88 & 3.28 & 89.11 & 5.37 & 1.79 & 82.44 & 6.15 & 2.05 \\
\hline Subchondral bone abnormalities & $3.15^{*}$ & 3.15 & $-2.43^{* *}$ & 1.05 & 0.21 & 1.86 & 36.78 & 8.09 & 2.70 & 24.67 & 5.43 & 1.81 \\
\hline Inflammation & 1.33 & 1,33 & -1.15 & 0.44 & -0.26 & 1.12 & 88.67 & 10.89 & 3.63 & 70.67 & 17.82 & 5.94 \\
\hline Abnormal calcification/ossification & 1.00 & - & -1.00 & - & - & - & 92.56 & 8.95 & 2.98 & 88.67 & 14.01 & 4.67 \\
\hline Vascularisation & 2.28 & 2.28 & $-2.08^{*}$ & 0.76 & -0.01 & 1.49 & 100.00 & 0.00 & 0.00 & 98.56 & 4.33 & 1.44 \\
\hline Surface/superficial assessment & 1.80 & 1.80 & -1.48 & 0.60 & -0.13 & 1.30 & 78.33 & 21.71 & 7.24 & 58.89 & 23.46 & 7.82 \\
\hline Middle/deep zone assessment & 1.97 & 1.97 & -1.72 & 0.66 & -0.09 & 1.36 & 75.56 & 18.78 & 6.26 & 67.11 & 11.22 & 3.74 \\
\hline Matrix staining & $4.07^{* *}$ & 4.07 & $-2.38^{*}$ & 1.36 & 0.41 & 2.26 & 79.67 & 11.05 & 3.68 & 70.44 & 6.89 & 2.30 \\
\hline Overall assessment & $2.59^{*}$ & 2.59 & $-1.96^{*}$ & 0.86 & 0.07 & 1.62 & 81.00 & 12.63 & 4.21 & 71.33 & 6.78 & 2.26 \\
\hline Overall rating & $3.388^{* *}$ & 6.606 & $-2.310^{*}$ & 1.129 & 0.259 & 1.959 & 76.55 & 9.83 & 328 & 66.91 & 6.76 & 2.25 \\
\hline
\end{tabular}

$N=9$. Poor effect, $D>0.2$; average effect, $D>0.5$; good effect, $D>0.8$

${ }^{*} p<0.05$

${ }^{* *} p<0.01$

${ }^{* * *} p<0.001$ 


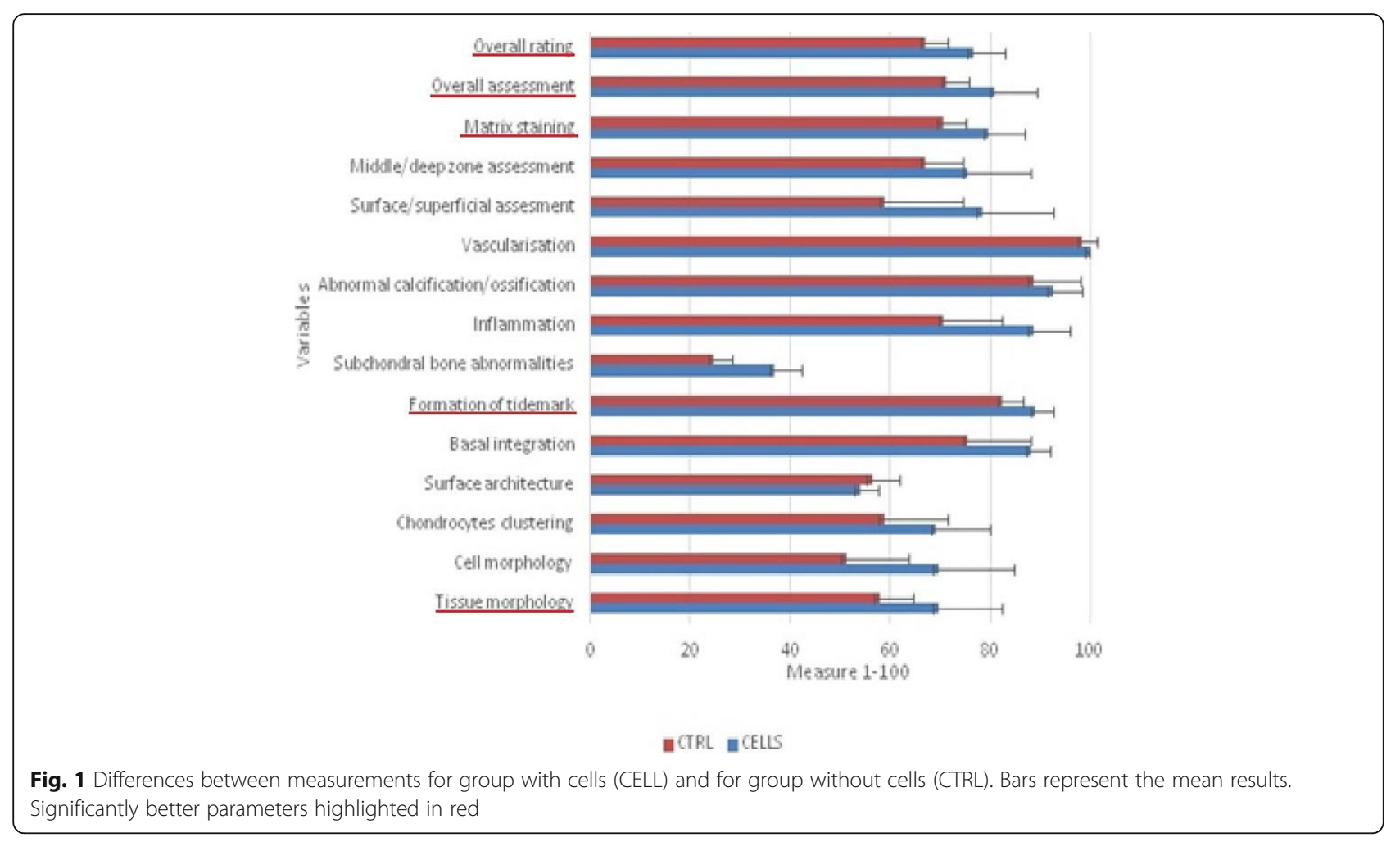

delivering them from another source (CTRL). This is similar to the microfracture technique, which is another marrow stimulation technique. The microfracture technique is not a perfect technique because it does not restore hyaline cartilage but leads to the production of fibrocartilage $[10,11]$. In the CELLS group, cells were obtained from bone marrow aspirates. Thus, bone marrow cells were present in both study groups. Chen et al. [19] showed that the depth of subchondral bone drilling determines the quality of cartilage regeneration, which is why we placed great importance on drilling the bone to a depth of $6 \mathrm{~mm}$ in our experiment. We have found many papers confirming the beneficial effects of platelet-rich plasma on the process of cartilage defect healing via the microfracture technique with collagen scaffolds, fibrin glue, or connective tissue membranes [20-22]. There are also many papers confirming the beneficial effect of treatment with mesenchymal stem cells (MSCs) obtained from bone marrow aspirates (BMAs) [23-25], including one- step techniques [26, 27]. Despite these reports, a few prospective studies comparing cell transplantation with the microfracture technique have not shown better results with cell therapy [28-30]. By reviewing the literature, we found reports that the chondrogenic potential of chondrocytes and chondrogenic stem cells declines with age, which suggests the much higher regenerative potential of juvenile chondrocytes [31-33]. This finding creates new possibilities in cell therapy. However, there are few reports of the use of these cells in clinical trials. In our experiment, we accurately created the study groups to provide almost identical conditions for comparison of the two therapeutic methods. In contrast to Adkisson et al., as a source of juvenile chondrocytes, we used growth cartilage instead of articular cartilage. Based on our results, we conclude that both the microfracture technique and scaffolds loaded with BMA-derived cells and growth plate chondrocytes achieve good results, with better results for the latter approach (microfracture, average microscopic score-

Table 6 Numbers of clusters in specific cartilage layers

\begin{tabular}{|c|c|c|c|c|c|c|c|c|c|c|c|c|c|c|c|c|c|c|c|c|}
\hline & $1 \mathrm{P}$ & $1 \mathrm{~L}$ & $2 \mathrm{P}$ & $2 \mathrm{~L}$ & $3 \mathrm{P}$ & $3 \mathrm{~L}$ & $4 \mathrm{~L}$ & $4 \mathrm{P}$ & $5 P$ & $5 \mathrm{~L}$ & $6 \mathrm{~L}$ & $6 \mathrm{P}$ & $7 \mathrm{~L}$ & $7 P$ & $8 \mathrm{~L}$ & $8 \mathrm{P}$ & $9 P$ & $9 \mathrm{~L}$ & $10 \mathrm{~L}$ & $10 P$ \\
\hline Clusters_superficial zone & $\begin{array}{l}+++ \\
(90)\end{array}$ & $\begin{array}{l}++ \\
(82)\end{array}$ & $\begin{array}{l}+ \\
(60)\end{array}$ & $\begin{array}{l}+++ \\
\text { (90) }\end{array}$ & $\begin{array}{l}+++ \\
\text { (92) }\end{array}$ & $\begin{array}{l}+ \\
(20)\end{array}$ & - & - & $\begin{array}{l}+ \\
(10)\end{array}$ & $\begin{array}{l}+++ \\
\text { (89) }\end{array}$ & $\begin{array}{l}++ \\
(10)\end{array}$ & $\begin{array}{l}+ \\
(10)\end{array}$ & $\begin{array}{l}+ \\
(10)\end{array}$ & $\begin{array}{l}- \\
(10)\end{array}$ & $\begin{array}{l}- \\
(0)\end{array}$ & $\begin{array}{l}- \\
(0)\end{array}$ & $\begin{array}{l}+ \\
(5)\end{array}$ & $\begin{array}{l}+ \\
(20)\end{array}$ & $\begin{array}{l}- \\
(0)\end{array}$ & $\begin{array}{l}\overline{-} \\
(0)\end{array}$ \\
\hline Clusters_-middle zone & $\begin{array}{l}+ \\
(60)\end{array}$ & $\begin{array}{l}+ \\
(40)\end{array}$ & $\begin{array}{l}+ \\
(20)\end{array}$ & $\begin{array}{l}+ \\
(50)\end{array}$ & $\begin{array}{l}+++ \\
\text { (85) }\end{array}$ & $\begin{array}{l}+ \\
(40)\end{array}$ & - & - & $\begin{array}{l}+ \\
(10)\end{array}$ & $\begin{array}{l}+ \\
(60)\end{array}$ & $\begin{array}{l}+ \\
(20)\end{array}$ & $\begin{array}{l}+ \\
(10)\end{array}$ & $\begin{array}{l}+ \\
(20)\end{array}$ & $\begin{array}{l}+ \\
(40)\end{array}$ & $\begin{array}{l}+ \\
(20)\end{array}$ & $\begin{array}{l}+ \\
(20)\end{array}$ & $\begin{array}{l}+ \\
(10)\end{array}$ & $\begin{array}{l}+ \\
(30)\end{array}$ & $\begin{array}{l}+ \\
\text { (30) }\end{array}$ & $\begin{array}{l}+ \\
(10)\end{array}$ \\
\hline Clusters_deep zone & $\begin{array}{l}++ \\
(80)\end{array}$ & $\begin{array}{l}+ \\
(20)\end{array}$ & $\begin{array}{l}+ \\
(20)\end{array}$ & $\begin{array}{l}+++ \\
(90)\end{array}$ & $\begin{array}{l}++ \\
(80)\end{array}$ & $\begin{array}{l}+ \\
(35)\end{array}$ & - & - & $\begin{array}{l}+ \\
(25)\end{array}$ & $\begin{array}{l}++ \\
(75)\end{array}$ & $\begin{array}{l}+ \\
(55)\end{array}$ & $\begin{array}{l}+ \\
(45)\end{array}$ & $\begin{array}{l}++ \\
(80)\end{array}$ & $\begin{array}{l}+ \\
(20)\end{array}$ & $\begin{array}{l}+ \\
(55)\end{array}$ & $\begin{array}{l}++ \\
(65)\end{array}$ & $\begin{array}{l}+++ \\
(90)\end{array}$ & $\begin{array}{l}+ \\
(80)\end{array}$ & $\begin{array}{l}+ \\
(75)\end{array}$ & $\begin{array}{l}+ \\
\text { (35) }\end{array}$ \\
\hline
\end{tabular}


Table 7 Statistical analysis

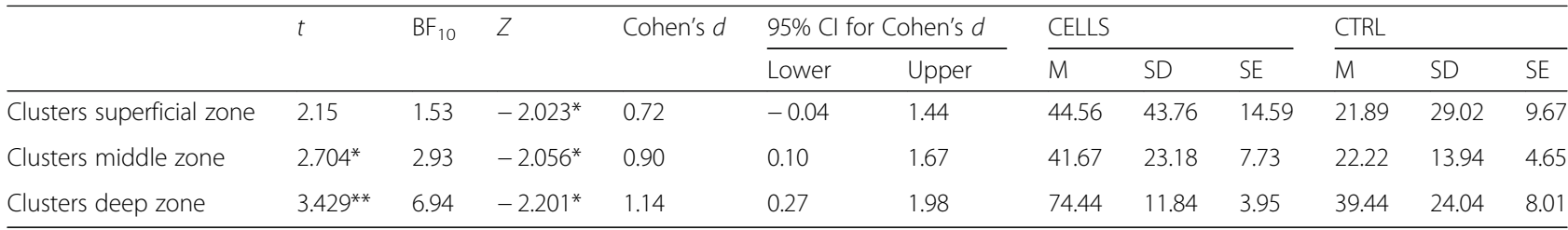

$N=9$. Poor effect, $D>0.2$; average effect, $D>0.5 ;$ good effect, $D>0.8$

${ }^{*} p<0.05$

${ }^{* *} p<0.01$

$*^{* *} p<0.001$

70.44\%; scaffolds with cells, average microscopic score$79.61 \%)$. What is worth emphasising in terms of cartilage regeneration is that we observed the formation of many chondrocyte colonies or clusters. Regarding the histology of cartilage, chondrocyte clusters are typical in osteoarthritis $[15,16]$. Other causes of cluster formation include excessive joint loading, articular cartilage damage, and joint immobilisation [33-37]. After analysing a study reported by Lotz et al. [38], we can explain the presence of these clusters by the initial stage of the regeneration process and the response of the newly created cartilage to mechanical loading. In the literature, there are reports of the presence of chondrocyte clusters in cartilage models of repair procedures. Makino et al. described the presence of clusters in cartilage after treatment with osteochondral allografts [39]. The main feature of clusters related to osteoarthritis versus cartilage regeneration is collagen type II expression with no expression of collagen type I or X [40], but we did not analyse this difference in our work. In analogy to the results of a rabbit model [39], in our work, we observed an increased number of clusters in the middle and deep cartilage layers, which, in our opinion, is a manifestation of the cartilage repair process starting from the deeper layers of the cartilage on the subchondral bone side. Undoubtedly, the presence of chondrocyte clusters is an interesting and not fully explained manifestation of the cartilage response to the stress factor and requires further observation. Based on our results, we believe that the addition of immature chondrocytes provides new possibilities for articular cartilage treatment.

\section{Conclusions}

1. Growth plate chondrocytes have a high chondrogenic potential and could thus create new possibilities for cartilage cell therapy.

2. The implantation of a hyaluronic acid scaffold loaded with bone marrow-derived MSCs and chondrocytes isolated from growth plates is a good method for the treatment of cartilage defects in immature patients.

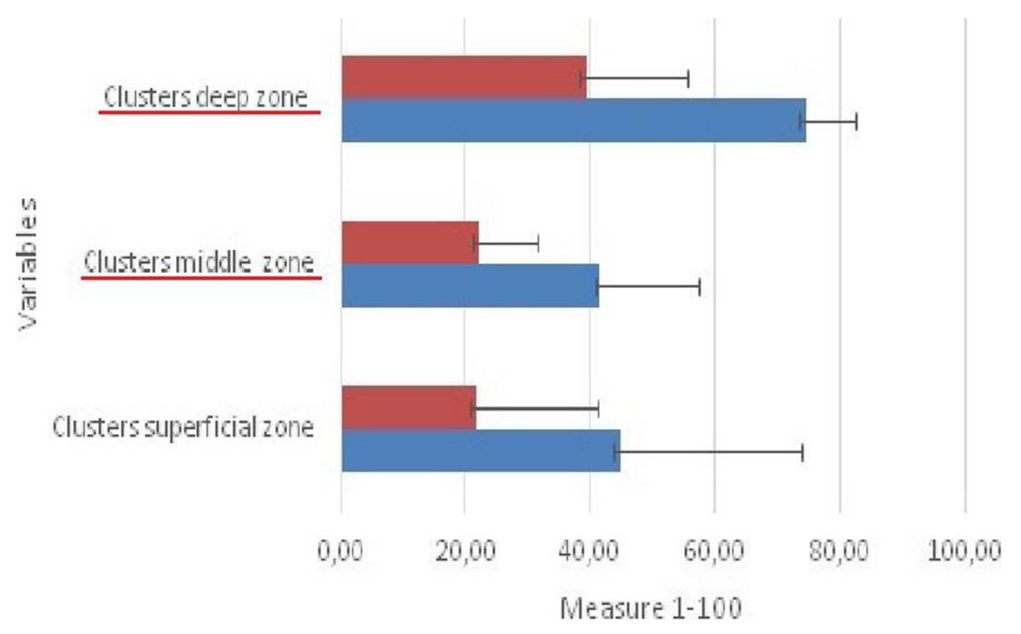

CTRL $\square$ CELLS

Fig. 2 Differences between number of chondrocyte clusters for group with cells (CELL) and for group without cells (CTRL). Bars represent the mean results. Significantly better parameters highlighted in red 


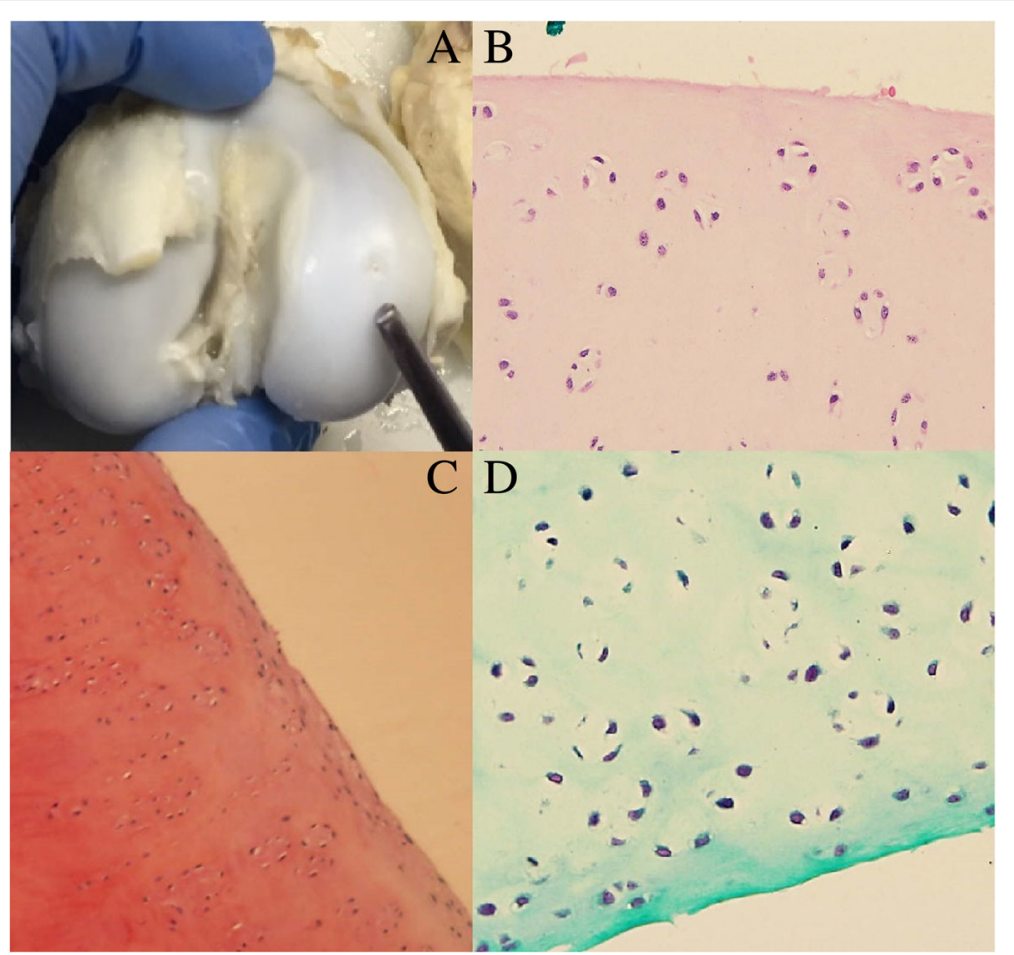

Fig. 3 Knee 1P (treated with cells) a Macroscopic evaluation. b Microscopic view of chondrocyte clusters in regenerated cartilage (200x, H\&E staining) c Microscopic view of chondrocyte clusters in regenerated cartilage (Safranin O staining). $\mathbf{d}$ Microscopic view of chondrocyte clusters in regenerated cartilage (Masson staining)

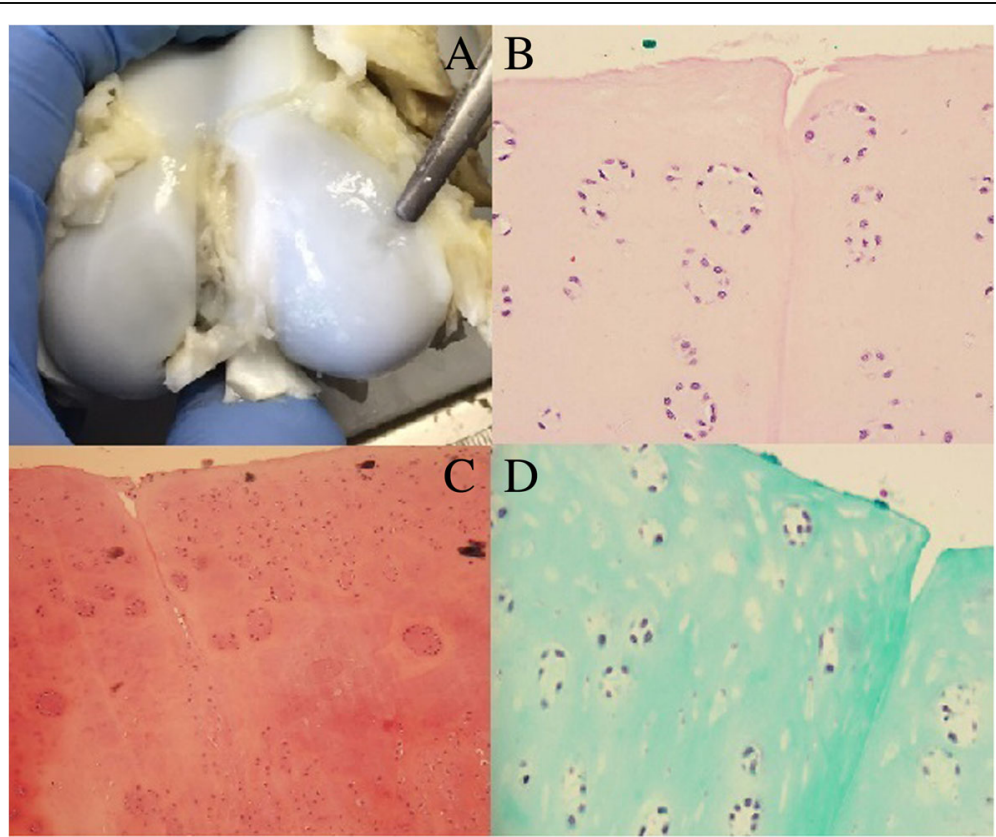

Fig. 4 Knee $1 \mathrm{~L}$ (treated with microfracture technique) a Macroscopic evaluation. b Microscopic view of chondrocyte clusters in regenerated cartilage (200x, H\&E staining). c Microscopic view of chondrocyte clusters in regenerated cartilage (Safranin O staining). d Microscopic view of chondrocyte clusters in regenerated cartilage (Masson staining) 
3. Cartilage repair based on the implantation of a scaffold loaded with BMA-derived cells supplemented with autologous growth plate chondrocytes achieves better results than the microfracture technique (overall microscopic rating).

4. Chondrocyte clustering is a manifestation of the cartilage repair process but requires further observation.

\section{Study limitations}

1. The study group was relatively small (ten pigs).

2. Due to the small study group, there was no group consisting of pigs with an untreated cartilage lesion to assess potential for spontaneous regeneration.

\section{Additional files}

Additional file 1: Table S1. Cartilage repair assessment ICRS. (DOCX $18 \mathrm{~kb}$ ) Additional file 2: Table S2. ICRS II. (DOCX $19 \mathrm{~kb})$

\section{Abbreviations}

ACl: autologous chondrocyte implantation; BMA: bone marrow aspirate; ESCs: embryonic stem cells; iPSCs: induced pluripotent stem cells; MACl: matrix-induced autologous chondrocyte implantation; MSCs: mesenchymal stem cells

\section{Acknowledgements}

The funders played no role in the study.

\section{Authors' contributions}

RT contributed to the study design, surgery, analysis, and interpretation of data. $Ł W$ contributed to the study design, surgery, analysis, and interpretation of data. AG contributed to the study design, analysis, and interpretation of data. All authors read and approved the final manuscript.

\section{Funding}

The study was wholly funded by a grant from the Medical University of Silesia.

\section{Availability of data and materials}

All research data are available from the Medical University of Silesia, Department of Pediatric Traumatology and Orthopedy, Katowice, Poland.

\section{Ethics approval and consent to participate}

We received permission for the implementation of our study from the Local Bioethics Committee of the Medical University of Silesia in Katowice (resolution number 29/2016 from 12/04/2016).

\section{Consent for publication}

Not applicable.

\section{Competing interests}

The authors declare that they have no competing interests.

\section{Author details}

'Department of Pediatric Traumatology and Orthopedy, Silesian Medical University, Katowice, Poland. ${ }^{2}$ Institute of Physics, University of Silesia, Katowice, Poland.
Received: 15 March 2019 Accepted: 30 July 2019

Published online: 15 August 2019

\section{References}

1. Karuppal R. Current concepts in the articular cartilage repair and regeneration. J Orthop. 2017;19(14):A1-3.

2. Rai $\mathrm{V}$, Dilisio MF, Dietz NE, Agrawal DK. Recent strategies in cartilage repair: a systemic review of the scaffold development and tissue engineering. J Biomed Mater Res A. 2017:105:2343-54.

3. Nam Y, Rim YA, Lee J, Ju JH. Current therapeutic strategies for stem cellbased cartilage regeneration. Stem Cells Int. 2018;25:8490489.

4. Tuan RS, Boland G, Tuli R. Adult mesenchymal stem cells and cell-based tissue engineering. Arthritis Res Ther. 2003;5:32-45.

5. Li MH, Xiao R, Li JB, Zhu G. Regenerative approaches for cartilage repair in the treatment of osteoarthritis. Osteoarthritis Cartilage. 2017;25:1577-87.

6. Mardones R, Jofré CM, Tobar L, Minguell JJ. Mesenchymal stem cell therapy in the treatment of hip osteoarthritis. J Hip Preserv Surg. 2017:4:159-63.

7. Nasu M, Takayama S, Umezawa A. Efficiency of human epiphyseal chondrocytes with differential replication numbers for cellular therapy products. Biomed Res Int. 2016;2016:6437658

8. Phull AR, Eo SH, Abbas Q, Ahmed M, Kim SJ. Applications of chondrocytebased cartilage engineering: an overview. Biomed Res Int. 2016;2016: 1879837.

9. Pak J, Lee JH, Kartolo WA, Lee SH. Cartilage regeneration in human with adipose tissue-derived stem cells: current status in clinical implications. Biomed Res Int 2016:2016:4702674

10. Steadman JR, Briggs KK, Rodrigo JJ, Kocher MS, Gill TJ, Rodkey WG. Outcomes of microfracture for traumatic chondral defects of the knee: average 11-year follow-up. Arthroscopy. 2003;19:477-84.

11. Solheim E, Hegna J, Inderhaug E, Øyen J, Harlem T, Strand T. Results at 1014 years after microfracture treatment of articular cartilage defects in the knee. Knee Surg Sports Traumatol Arthrosc. 2016;24:1587-93.

12. Iwamoto M, Ohta Y, Larmour C, Enomoto-Iwamoto M. Toward regeneration of articular cartilage. Birth Defects Res C Embryo Today. 2013;99:192-202.

13. Gobbi A, Scotti C, Karnatzikos G, Mudhigere A, Castro M, Peretti GM. Onestep surgery with multipotent stem cells and Hyaluronan-based scaffold for the treatment of full-thickness chondral defects of the knee in patients older than 45 years. Knee Surg Sports Traumatol Arthrosc. 2017;25:2494-501.

14. Gobbi A, Whyte GP. One-stage cartilage repair using a hyaluronic acidbased scaffold with activated bone marrow-derived mesenchymal stem cells compared with microfracture five-year follow-up. Am J Sports Med. 2016:44:2846-54.

15. Oldershaw RA. Cell sources for the regeneration of articular cartilage: the past, the horizon and the future. Int J Exp Pathol. 2012;93:389-400.

16. Kouri JB, Jimenez SA, Quintero M, Chico A. Ultrastructural study of chondrocytes from fibrillated and non-fibrillated human osteoarthritic cartilage. Osteoarthritis Cartilage. 1996:4:111-25.

17. Chu CR, Szczodry M, Bruno S. Animal models for cartilage regeneration and repair. Tissue Eng Part B Rev. 2010;16:105-15.

18. Frisbie DD, Morisset $\mathrm{S}, \mathrm{Ho} C \mathrm{C}$, et al. Effects of calcified cartilage on healing of chondral defects treated with microfracture in horses. Am J Sports Med 2006:34:1824-31.

19. Chen H, Hoemann CD, Sun J, Chevrier A, McKee MD, Shive MS, Hurtig M, Buschmann MD. Depth of subchondral perforation influences the outcome of bone marrow stimulation cartilage repair. J Orthop Res. 2011;29:1178-84.

20. Qi YY, Chen $X$, Jiang YZ, Cai HX, Wang LL, Song XH, Zou XH, Ouyang HW. Local delivery of autologous platelet in collagen matrix simulated in situ articular cartilage repair. Cell Transplant. 2009;18:1161-9.

21. Milano G, Sanna Passino E, Deriu L, Careddu G, Manunta L, Manunta A, Saccomanno MF, Fabbriciani C. The effect of platelet rich plasma combined with microfractures on the treatment of chondral defects: an experimental study in a sheep model. Osteoarthritis Cartilage. 2010;18:971-80.

22. Zhu Y, Yuan M, Meng HY, Wang AY, Guo QY, Wang Y, Peng J. Basic science and clinical application of platelet-rich plasma for cartilage defects and osteoarthritis: a review. Osteoarthritis Cartilage. 2013;21:1627-37.

23. Im GI, Kim DY, Shin JH, Hyun CW, Cho WH. Repair of cartilage defect in the rabbit with cultured mesenchymal stem cells from bone marrow. J Bone Joint Surg Br. 2001;83:289-94.

24. Jung M, Kaszap B, Redöhl A, Steck E, Breusch S, Richter W, Gotterbarm T. Enhanced early tissue regeneration after matrix-assisted autologous 
mesenchymal stem cell transplantation in full thickness chondral defects in a minipig model. Cell Transplant. 2009;18:923-32.

25. Chahla J, Dean CS, Moatshe G, Pascual-Garrido C, Serra Cruz R, LaPrade RF. Concentrated bone marrow aspirate for the treatment of chondral injuries and osteoarthritis of the knee: a systematic review of outcomes. Orthop J Sports Med. 2016:4:2325967115625481.

26. Gobbi A, Karnatzikos G, Scotti C, Mahajan V, Mazzucco L, Grigolo B. Onestep cartilage repair with bone marrow aspirate concentrated cells and collagen matrix in full-thickness knee cartilage lesions. Results at 2-year follow-up. Cartilage. 2011;2:286-99.

27. Enea D, Cecconi S, Calcagno S, Busilacchi A, Manzotti S, Gigante A. Onestep cartilage repair in the knee: collagen-covered microfracture and autologous bone marrow concentrate. A pilot study. Knee. 2015;22:30-5.

28. Knutsen G, Engebretsen L, Ludvigsen TC, et al. Autologous chondrocyte implantation compared with microfracture in the knee. A randomized trial. J Bone Joint Surg Am. 2004;86:455-64.

29. Knutsen $G$, Drogset JO, Engebretsen $L$, et al. A randomized trial comparing autologous chondrocyte implantation with microfracture. Findings at five years. J Bone Joint Surg Am. 2007;89:2105-12.

30. Saris DB, Vanlauwe J, Victor J, et al. Characterized chondrocyte implantation results in better structural repair when treating symptomatic cartilage defects of the knee in a randomized controlled trial versus microfracture. Am J Sports Med. 2008;36:235-46.

31. Adkisson HD, Martin JA, Amendola RL, Milliman C, Mauch KA, Katwal AB, Seyedin M, Amendola A, Streeter PR, Buckwalter JA. The potential of human allogeneic juvenile chondrocytes for restoration of articular cartilage. Am J Sports Med. 2010;38:1324-33.

32. Zheng H, Martin JA, Duwayri Y, Falcon G, Buckwalter JA. Impact of aging on rat bone marrow derived stem cell chondrogenesis. J Gerontol A Biol Sci Med Sci. 2007;62:136-48.

33. Betsch M, Schneppendahl J, Thuns S, Herten M, Sager M, Jungbluth P, Hakimi M, Wild M. Bone marrow aspiration concentrate and platelet rich plasma for osteochondral repair in a porcine osteochondral defect model. PLoS One. 2013;8:e71602.

34. Lee GM, Paul TA, Slabaugh M, Kelley SS. The incidence of enlarged chondrons in normal and osteoarthritic human cartilage and their relative matrix density. Osteoarthritis Cartilage. 2000;8:44-52.

35. Okazaki R, Sakai A, Nakamura T, Kunugita N, Norimura T, Suzuki K. Effects of transforming growth factor beta and basic fibroblast growth factor on articular chondrocytes obtained from immobilised rabbit knees. Ann Rheum Dis. 1996;55:181-6.

36. Marijnissen AC, van Roermund PM, TeKoppele JM, Bijlsma JW, Lafeber FP. The canine 'groove' model, compared with the ACLT model of osteoarthritis. Osteoarthritis Cartilage. 2002;10:145-55.

37. Lozoya KA, Flores JB. A novel rat osteoarthrosis model to assess apoptosis and matrix degradation. Pathol Res Pract. 2000;196:729-45.

38. Lotz MK, Otsuki S, Grogan SP, Sah R, Terkeltaub R, D'Lima D. Cartilage cell clusters. Arthritis Rheum. 2010;62:2206-18

39. Makino T, Fujioka H, Kurosaka M, Matsui N, Yoshihara H, Tsunoda M, et al. Histologic analysis of the implanted cartilage in an exact-fit osteochondral transplantation model. Arthroscopy. 2001;17:747-51.

40. Muldrew K, Chung M, Novak K, Schachar NS, Zernicke RF, McGann LE, et al. Evidence of chondrocyte repopulation in adult ovine articular cartilage following cryoinjury and long-term transplantation. Osteoarthritis Cartilage. 2001:9:432-9.

\section{Publisher's Note}

Springer Nature remains neutral with regard to jurisdictional claims in published maps and institutional affiliations.

Ready to submit your research? Choose BMC and benefit from:

- fast, convenient online submission

- thorough peer review by experienced researchers in your field

- rapid publication on acceptance

- support for research data, including large and complex data types

- gold Open Access which fosters wider collaboration and increased citations

- maximum visibility for your research: over $100 \mathrm{M}$ website views per year

At BMC, research is always in progress.

Learn more biomedcentral.com/submissions 